\title{
光電管を應用して各種の微量糖類を 比色定量する方法
}

\author{
(昭和十一年六月サ九日受領＼cjkstart昭和十一年九月廿五日印刷)
}

\author{
近藤金助村山仁 \\ 緒言
}

筆者 はセシウム光電管に三極萁空管を配したる光電光度計を朋方る際, 光電管の感光性と供試液 の吸光性とに適合したる浪光法を考案施行すれば各種の呈色液について 合理的に且つ精密に比色定 量をなし得ることを触驗例をあげて報告した。

加之此の光度計を利用すれば色度の外飞色調及び溷䍠度を比胶し得るのみならす着色液又は溷罚 液中の呈色反㮣をる測定し得るととを記述したのである.

各種の糖類仼對して Tillmans 及 Sórensen の Orcin-硫酸法を應用すれば糖類の種類によつて特異 的な色調と绝度とを呈するのでする.Sórensen 及 Haugaard ${ }^{23}$ は此の色調と色度とを Stufenphotome-

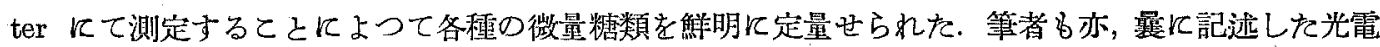
光度計を利用してる Sórensen 及 Haugaard の法による色調と色度とを測定し得ることを證し得 た. 郎ち此の光電光度計を用みても Tillmans 及 Sorensen の Orcin-硫酸法によつて糖類の微量を比 色定量し得たれば竝に報告する次第である。

\section{Tillmans 及 Sórensen $の$ Orcin-硫酸法}

試藥は次の二種である.

（1）Orcin-液: 濃硫酸 1 容に水 4 容を混じたる稀薄硫酸 $100 \mathrm{ce}$ 中に $2 \mathrm{~g}$ D Orein 結晶を溶解せし めるるの

（2）反應硫酸：濃硫酸 6 容に水 4 容を混じたるもの

糖液 (約 $0.02 \%$ 位の水溶液) 1 cc を小型王氏有栓フラスコにとり之に Orcin 液 $2 \mathrm{cc}$ と反應硫酸 $15 \mathrm{cc}$ そを加 $80^{\circ}$ D溫湯中にて一定時間 (5 分乃至 30 分) 加溫して呈色せしめをる後暗所に於て水水中 にて急冷して呈色反應の進行を止めて標準液又は對照液と此色するのである，光も筫驗中溫湯の溫， 度が 1-2 度上下しても呈色度に何等の影響を與へないととは辐驗されてある。

此の方法は始め Tillmans 及 Philippi ${ }^{32}$ が蛋白中の糖類を定量した時【創案したるのを S6rensen 及

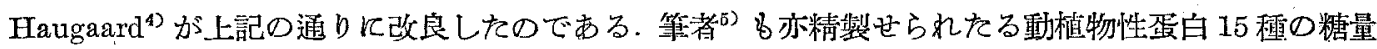
を Tillmans 及 Philippi の方法によつて Glucose として定量したてとがある. けれども其の時の呈色

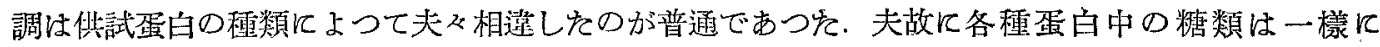
Glucose ではないととを制定して置いたのである.而して筆者の經驗によつてる各程の糖類に對して Tillmans 及 Sórensen Orcin-硫酸法を試みる時は糖類の浱度によつて色度を異にするは刨諭のて

1) 近藤, 村山：本誌，57(1936), 772. 2) M. Sórensen, G." Haugaard: Biochem. Z., 260(1933), 247.
3) Tillmans, Philippi : Biochem. Z., 215(1929), 36.
4) 前出
5) 近藤, 村山：本誌. 54(1933), 351 . 
そ色調は糖類の極類に上つて特異的であるばかりでなく加溫反應時間につれて特異的に變化するの である.

例へば Glucose の $0.02 \%$ 水溶液に Orcin-硫酸法を試みれば色調は最初より帶黄赤であつて州溫反 應時間の經過と共に色度を强めるのみである，然るに Galactose の $0.02 \%$ 水溶液に Orcin-硫酸法 を陚むれば始めの色調は深紅色であるが州溫反應時間が 15 分に達すれば帶黃し 25 分一30分間反應

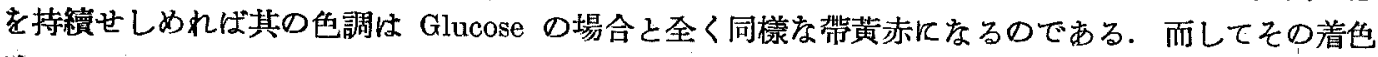
液の吸收スペクトルは前報の第 5 圖に示しである處の Glucose のものと全く同樣になる. 即ち25 分 乃至 30 分の加溫反應後飞於ては Glucose, Galactose 間の區別は肉眼にては刎論のてと吸收スペクト

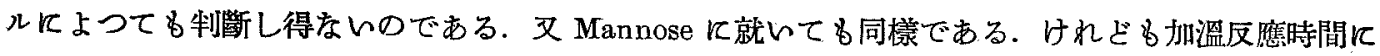
よる色調の變化は各種の糖類にありては特異的である。而して此の色調の特異的な 變化を前記の光 電光度計によつて测定し得るが故に各種の㤑類を定性的に識別し得るわけである。のみなら和各種 糖類のOrcin-硫酸法に上る呈色度は糖量 (一定範園内の) 飞比例するこ之を知り得をれば本法の雇用 によつて各種糖類の定性並に定量を企てたのである.

\section{實 驗 成 綪}

各種の糖液に Tillmans 及 Śrensen のOrcin-硫酸法を適朋した時の呈垈液は可視光線の一部をば 吸收するけれども近赤外線をば全然透通することは前報の第5圖に一例として Glucose の場合を示 した通りである．而して筆者の光電光度計に於ては光源としては白熱電球を用る. 光電管としては近 赤外線によく感光するセシウム光電管を利用してある. 夫故に上記の如を特性を有する呈色液の吸 光度を此の光電光度計によつて 测定する場合には近赤外線を吸收除去し得る滤光液を作用する必要 あることは前堑に於て詳說した通りである。

そこで筆者は 1cc 中に銅として $11 \mathrm{mg}$ を溶解せる硫酸銅液(少量の硫酸を添扣)を滤光液 $\mathrm{A}$ をな しヌ $1 \mathrm{cc}$ 中に銅として $4.8 \mathrm{mg}$ を溶解せるアンモ二ヤ性硫酸銅液を滤光液 B となした，此等の滤光 液が本實驗の目的に沿ひ得ることは前報の第 5 龽に明示した通りである. 而して此の滤光液は厚さ “ $1 \mathrm{~cm}$ の硝子管に入れて使用したのであるが滤光液の莀度は光源電球 ${ }^{6}$ より發出する最大の光度に於

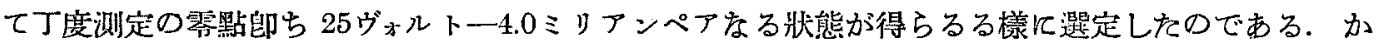

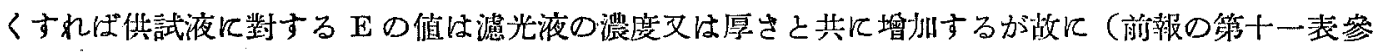
照) 呈色液が加溫反應時間の差によつて示す處の色度亚びに色調の變化を最も明瞭, 正猚に知り得る わけである.

(1) 微量糖類の定性試驗

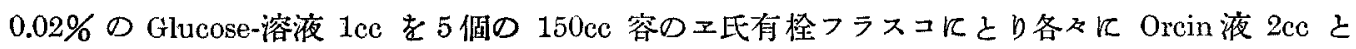
反應硫酸液 $15 \mathrm{cc}$ とを扣人 $80^{\circ}$ の温湯中にて呈出反應せしめる. 最初から5分を過ぎる腐にフラス コ1個宛を溫湯中からとり出し直ちに暗所の水水中につけて急冷して呈色反應を停此せしむれば此 處に反應時間を異にする5傦の呈色液を得るわけである．此の呈色液を夫及長さ $2 \mathrm{~cm}$ の硝子管に入

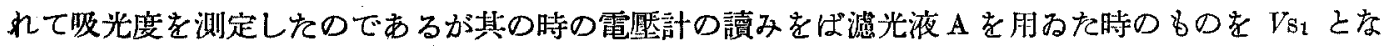

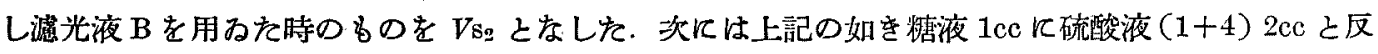
應硫酸 $15 \mathrm{cc}$ とを加へて前同樣に $80^{\circ}$ の溫湯中にて加溫したるるのを對照液となした. 此の時には

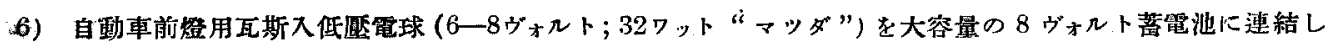
て光源とした。 


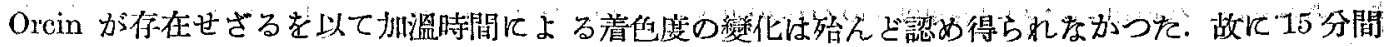
加溫したものを對照液となし之を急冷徭前同樣に長さ $2 \mathrm{~cm}$ の硝子管に入れて吸光度を测定した. そ

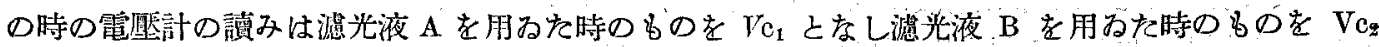
となした.

然る上 $E_{1}=\log \left(V_{c_{1}} / V_{s_{1}}\right)$ 及び $E_{2}=\log \left(V \mathrm{c}_{2} / V_{\mathrm{s}_{2}}\right)$ を賞出すれば加溫反應時間を異にする上記 5

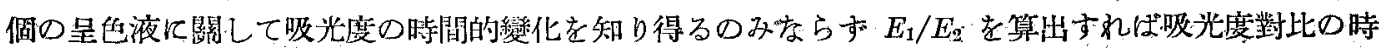
間的變化を知り得るのである．前者は Sórensen 及 Haugnard の時䦌曲線に相當し後者ね對比曲線に 相虽するのであつて Glucose-液とついての测定結果を示せ㳊第一表の通りである.

上記と同樣にして六炭糖 (Galactose, Mannose 及び Fructose) 並に五炭糖 (Arabinose, Xylose 及 びRhamnose）反就いて吸光度を測定した紹果を總括したものは第二表である．而して第一表と第二 表の数值を圖示すれば第 1 圖乃至第 3 圖の如くに吸光度の 時間曲線 己對比曲線とになるのである. 而して此の時間曲線並飞對比曲線の形狀は各種の糖類に關して特異的であるのみならす對比曲線の

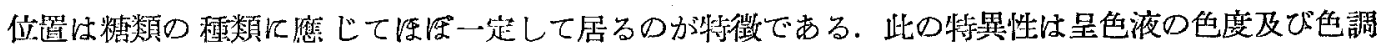
が加溫反應時閏的に糖の種類に應じて特異的に變化することを示すのであつて此の特異性によつて 各種の糖類蜼暸に識別し得られるのである。

第一表

Glucose $\odot$ 加溫時間と吸光度 $(E)$

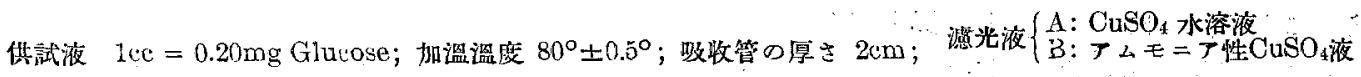

\begin{tabular}{|c|c|c|c|c|c|c|c|c|c|c|}
\hline \multicolumn{3}{|c|}{ 苗驗液の組成 } & \multirow{2}{*}{$\begin{array}{c}\text { 加 } \\
\text { 溫 } \\
\text { 晴 } \\
\text { 間 } \\
\text { (分) } \\
\end{array}$} & \multirow{2}{*}{$\frac{\text { 濾 }}{V}$} & 光 液 & \multirow{2}{*}{$\frac{\text { A. }}{E_{1}}$} & \multirow{2}{*}{$\frac{\text { 熟 }}{V}$} & 光 液 & B. & \multirow{2}{*}{$\begin{array}{l}\text { 對 此 } \\
\left(E_{1} / E_{2}\right)\end{array}$} \\
\hline 糖 $\mathrm{cc}^{\text {液 }}$ & $\begin{array}{c}\text { Orcin 液 } \\
\quad \mathrm{ec}\end{array}$ & 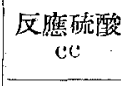 & & & $\log V$ & & & $\log V$ & $\dot{E}_{2}$ & \\
\hline 1. & $(2) \%$ & 15 & 15 & 23.92 & 1.37876 & - & 21.40 & 1.33041 & - & - \\
\hline$"$ & 2 & $"$ & 5 & 20.03 & 1.30168 & 0.07708 & 19.85 & 1.29776 & 0.03265 & 2.36 \\
\hline$"$ & $"$ & $"$ & 10 & 17.78 & 1.24993 & 0.12883 & 19.40 & 1.28780 & 0.04261 & 3.02 \\
\hline " & $"$ & $\prime \prime$ & 15 & 17.20 & 1.23555 & 0.14323 & 19.02 & 1.27921 & 0.05120 & 2.80 \\
\hline$"$ & $"$ & $"$ & 20 & 17.02 & 1.23096 & 0.14780 & 18.85 & 1.27531 & 0.05510 & 2.68 \\
\hline$"$ & $"$ & $"$ & 25 & 17.02 & 1.23096 & 0.14780 & 18.88 & 2.27600 & 0.05441 & 2.72 \\
\hline
\end{tabular}

※ Orcin 含含ざる $1: 4$ 唡酸

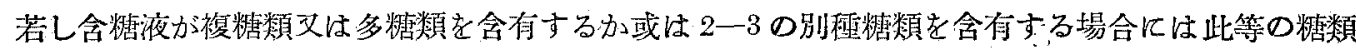

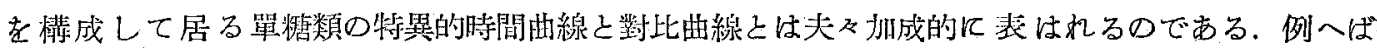
Sucrose 及び Lactose についての筫驗結果を示して此の事を寶證して見るならば次の通りである。

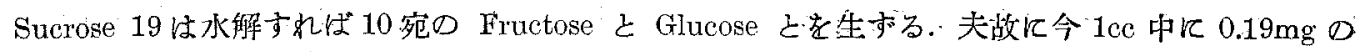

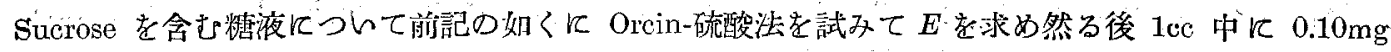

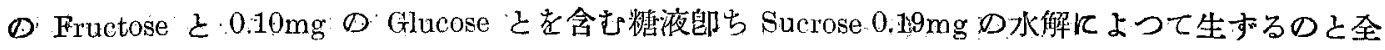
く同量の Fructose と Glucose と考む糖液並に 1cc 中の含糖量は $0.20 \mathrm{mg}$ であるが $3: 1$ 及び 1:3 
第 云裴

各種糖類の加溫時間之吸光度 $E$ (時間曲線乙對比曲線)

供試糖液 $1 \mathrm{cc}$ 中の糖量 $0.20 \mathrm{mg}$ : 加溫溫救 $80^{\circ} \pm 0.5^{\circ}$ :

吸牧管の厚さ $2 \mathrm{~cm}$

\begin{tabular}{|c|c|c|c|c|}
\hline \multirow{2}{*}{ 楉 類 } & \multirow{2}{*}{$\begin{array}{c}\text { 扣 盖 } \\
\text { 時 閒 } \\
\text { (分) }\end{array}$} & 滤光液 A & 滤光㳂 B & \multirow{2}{*}{ 龂比 $\left(E_{1} / E_{2}\right)$} \\
\hline & & $E_{1}$ & $E_{2}$ & \\
\hline \multirow{5}{*}{ Glucose } & 5 & 0.07708 & 0.03265 & 2.36 \\
\hline & 10 & 0.12883 & 0.04261 & 3.02 \\
\hline & $1 \tilde{0}$ & 0.14323 & 0.05120 & 2.80 \\
\hline & 20 & 0.14780 & 0.05510 & 2.68 \\
\hline & 25 & 0.14780 & 0.05441 & 2.72 \\
\hline \multirow{5}{*}{ Galactose } & 5 & 0.14956 & 0.03090 & 4.84 \\
\hline & 10 & 0.16771 & 0.03409 & 4.92 \\
\hline & 15 & 0.16058 & 0.03823 & 4.20 \\
\hline & 20 & 0.145034 & 0.03846 & 3.78 \\
\hline & 25 & 0.14037 & 0.03547 & 3.96 \\
\hline \multirow{5}{*}{ Mannose } & 5 & 0.13599 & 0.02812 & 4.84 \\
\hline & 10 & 0.13963 & 0.03706 & 3.77 \\
\hline & 15 & 0.13084 & 0.03337 & 3.92 \\
\hline & 20 & 0.13059 & 0.03268 & 4.00 \\
\hline & 25 & 0.13059 & 0.03245 & 4.02 \\
\hline \multirow{5}{*}{ Fructose } & 5 & 0.09173 & 0.01917 & 4.79 \\
\hline & 10 & 0.08749 & 0.02188 & 4.00 \\
\hline & 15 & 0.08862 & 0.02188 & 4.05 \\
\hline & 20 & 0.09149 & 0.02828 & 3.24 \\
\hline & 25 & 0.09925 & 0.02874 & 3.45 \\
\hline \multirow{5}{*}{ Arabinose } & 5 & 0.22470 & 0.03928 & 5.72 \\
\hline & 10 & 0.20536 & 0.03834 & 5.36 \\
\hline & 15 & 0.19890 & $0.03 \tilde{5} 99$ & 5.53 \\
\hline & 20 & 0.18983 & 0.03505 & 5.42 \\
\hline & 25 & 0.18864 & 0.03318 & 5.69 \\
\hline \multirow{5}{*}{ Xylose } & 5 & 0.22479 & 0.04190 & 5.36 \\
\hline & 10 & 0.20596 & 0.03982 & 5.17 \\
\hline & 15 & 0.19654 & 0.03701 & 5.31 \\
\hline & 20 & 0.19295 & 0.03818 & 5.05 \\
\hline & 25 & 0.19295 & 0.03584 & 5.38 \\
\hline \multirow{5}{*}{ Rhamnose } & 5 & 0.13178 & 0.03351 & 3.93 \\
\hline & . 10 & 0.13048 & 0.03304 & 3.95 \\
\hline & 15 & 0.13231 & 0.03027 & 4.37 \\
\hline & $20^{\prime}$ & 0.13545 & $0.03 \cap 96$ & 4.38 \\
\hline & 25 & 0.13808 & 0.03096 & 4.46 \\
\hline
\end{tabular}

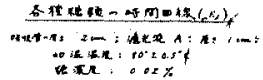

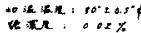

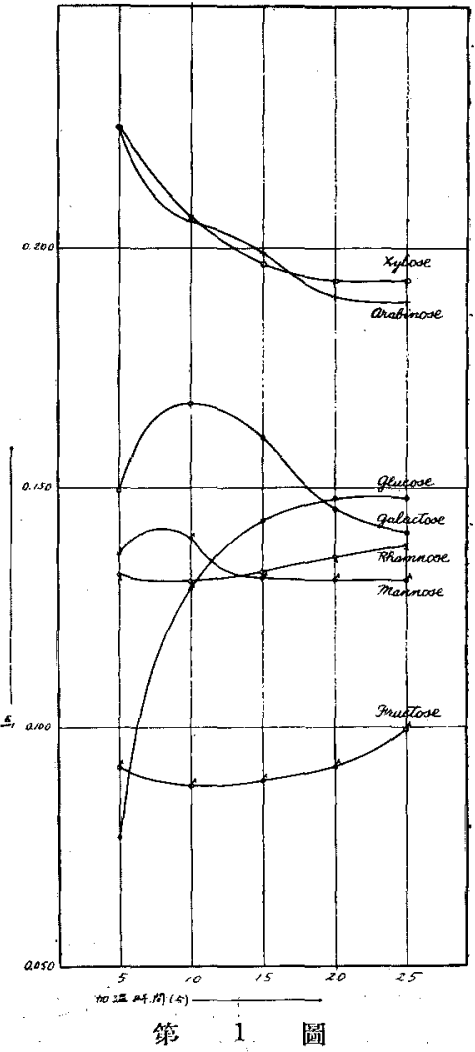

D Glucose-Fructose 混液 $の$ 三䅜に ついて前同樣に處理して $E$ の值 を求めて見たのである。其の綃舆 忙第三表の通りであつて之を圖示

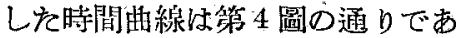
3.

Lactose D結晶は 1 分子の氷を 含むが故に絬晶 $0.2 \mathrm{mg}$ 老我解すれ ば丁度 $0.1 \mathrm{mg}$ 宛の Galactose 己 Glucose 亡老生ずるわけである。 夫故に 1ce 陑K $0.20 \mathrm{ng}$ O Lactose

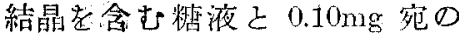
Galactose とGlucose と考含單 精泚液とについて Oroin-硫酸法を 


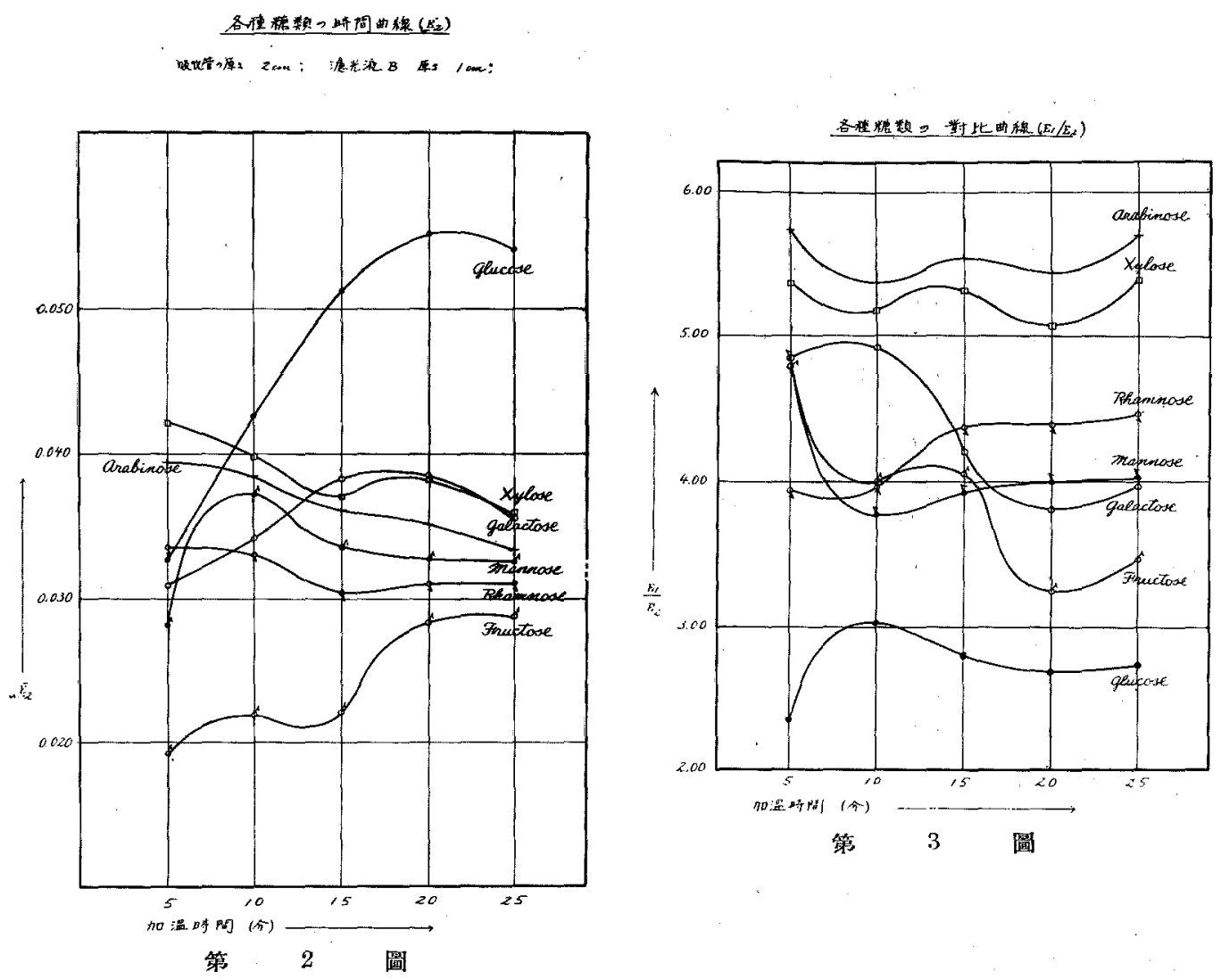

試みて $E$ の時間的變化を求めて見え. その結果は第 4 表と第 4 备とに示してある.

第 4 圖の時間曲線てよつて明瞭な通り Sucrose 又は Lactose の時間曲線俚其の權成單糖類の混合 液の時間曲線之全く一致するのみならす若し單糖類混合の比が Sucrose の水解物とは違つてGlucose： Fructose が 3:1 又は 1:3 の如くであれば夫及特異的な時間曲線を示すのである. 從つて對比曲線 亦特異的とをるのである。

斯くの如く時間曲線之對比曲線とは糖の種類により又混合比によつて特異的でする.夫故に或る 含糖液 (糖類, 配糖體又は蛋白の溶液) KOrcin-硫酸法を試みたる娞時間曲線己對比曲線之を求めれ ばその形狀と位置とによつて供試液中の糖の稞類を的確に斷定し得るのでする，而して 2 種或は 3 種 の糖類が混合する場合に於ても，先づその混合物に對する時間曲線己對比曲線とによつて糙の種類己

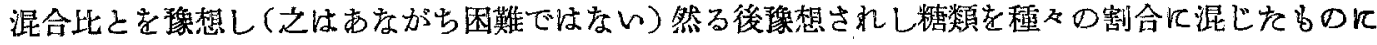
つんて $E$ の曲線を求むれ代供試液中の糖の整類と混合比を知り得るのである.

かくして本法によつて微量糖頪の定性を極めて正確になし得るわけである.

(2) 微量糖類の定量試驗

糖液にOrcin-硫酸法を試みを時の呈色度は或る範園內の濃度に於ては糖の溜度に比例するのであ る. 例人ば Glucose, Fructose, Arabinose 及び Rhamnose 等を夫ょ 1cc 中に $0.04 \mathrm{mg}-0.20 \mathrm{mg}$ 宛 合む糖液を調製し Orcin-硫酸法を試みて加溫反應時間を 20 分にして $E$ を測定して見た. 但しその 
第三表 Glucose-Fructose混液の吸光度 $(E)$

と Sucrose 溶液の吸光度 $(E)$ との比較

昅收管の厚さ $2 \mathrm{~cm}$

\begin{tabular}{|c|c|c|c|c|}
\hline 賽の & $\begin{array}{l}\text { 鰠驗液 } \\
\text { 1cc中 }\end{array}$ & 加㴘 & 滤 光液 A & 泖北波 $\mathrm{B}$ \\
\hline 中類 & $\begin{array}{c}\text { 桷 } \\
\mathrm{mg}\end{array}$ & (分) & $E_{1}$ & $E_{2}$ \\
\hline \multirow{7}{*}{ 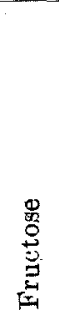 } & \multirow{5}{*}{ 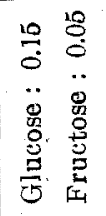 } & 5 & 0.065 & 0.015 \\
\hline & & 10 & 0.100 & 0.027 \\
\hline & & 15 & 0.116 & 0.030 \\
\hline & & 20 & 0.118 & 0.031 \\
\hline & & 25 & 0.122 & 0.031 \\
\hline & \multirow{5}{*}{ 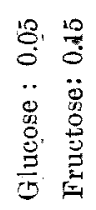 } & $\tilde{5}$ & 0.089 & 0.021 \\
\hline & & 10 & 0.098 & 0.025 \\
\hline$\omega$ & & $10 \bar{~}$ & 0.105 & 0.028 \\
\hline \multirow{7}{*}{ 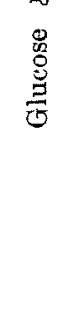 } & & 20 & 0.106 & 0.030 \\
\hline & & 25 & 0.110 & 0.029 \\
\hline & \multirow{5}{*}{ 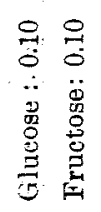 } & $\tilde{0}$ & 0.075 & 0.017 \\
\hline & & 10 & 0.100 & 0.025 \\
\hline & & 15 & $\overline{0.109}$ & $\overline{0.029}$ \\
\hline & & 20 & 0.112 & 0.030 \\
\hline & & 25 & 0.116 & 0.030 \\
\hline \multirow{5}{*}{ 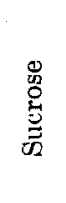 } & \multirow{5}{*}{$\begin{array}{l}0 \\
0 \\
0 \\
0 \\
0 \\
0 \\
0 \\
0 \\
0 \\
0\end{array}$} & 5 & 0.080 & 0.018 \\
\hline & & 10 & 0.100 & 0.025 \\
\hline & & 15 & 0.110 & 0.028 \\
\hline & & 20 & 0.112 & 0.030 \\
\hline & & 25 & 0.116 & 0.030 \\
\hline
\end{tabular}

第四表 Glucose-Galactose 混液の $E$ 之 Lactose 溶液の $E$ との比較 吸收管の厚さ $2 \mathrm{cma}$

\begin{tabular}{|c|c|c|c|c|}
\hline \multirow{2}{*}{$\begin{array}{l}\text { 筫の } \\
\text { 驗站 } \\
\text { 液 } \\
\text { 中類 }\end{array}$} & \multirow{2}{*}{ 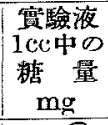 } & \multirow{2}{*}{ 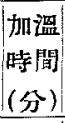 } & 濾光 液 $\mathrm{A}$ & 㦄光 液 $\mathrm{B}$ \\
\hline & & & $E_{1}$ & $E_{2}$ \\
\hline \multirow{5}{*}{ r. } & \multirow{5}{*}{ 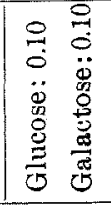 } & 5 & 0.107 & 0.020 \\
\hline & & 10 & 0.140 & 0.032 \\
\hline & & 15 & 0.137 & 0.031 \\
\hline & & 20 & 0.133 & 0.032 \\
\hline & & 25 & 0.133 & 0.032 \\
\hline \multirow{5}{*}{ 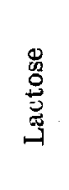 } & \multirow{5}{*}{ 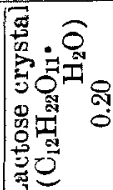 } & 5 & 0.105 & 0.019 \\
\hline & & 10 & 0.140 & 0.032 \\
\hline & & 15 & 0.138 & 0.032 \\
\hline & & 20 & 0.133 & 0.031 \\
\hline & & 25 & 0.132 & 0.031 \\
\hline
\end{tabular}

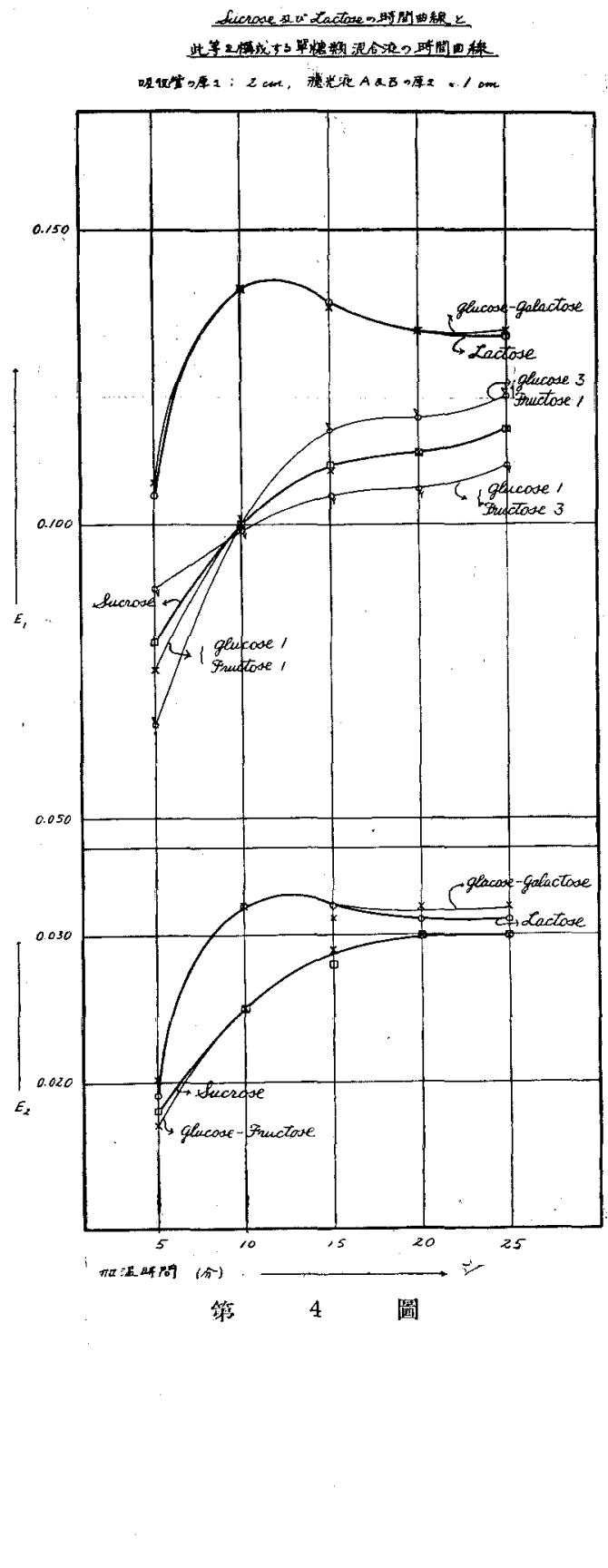


第五表

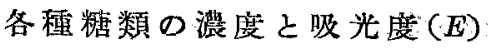

加溫時間 20分:：硫酸銅滤光液 厚さ $2 \mathrm{~cm}:$ 财收管の厚さ $2 \mathrm{~cm}$

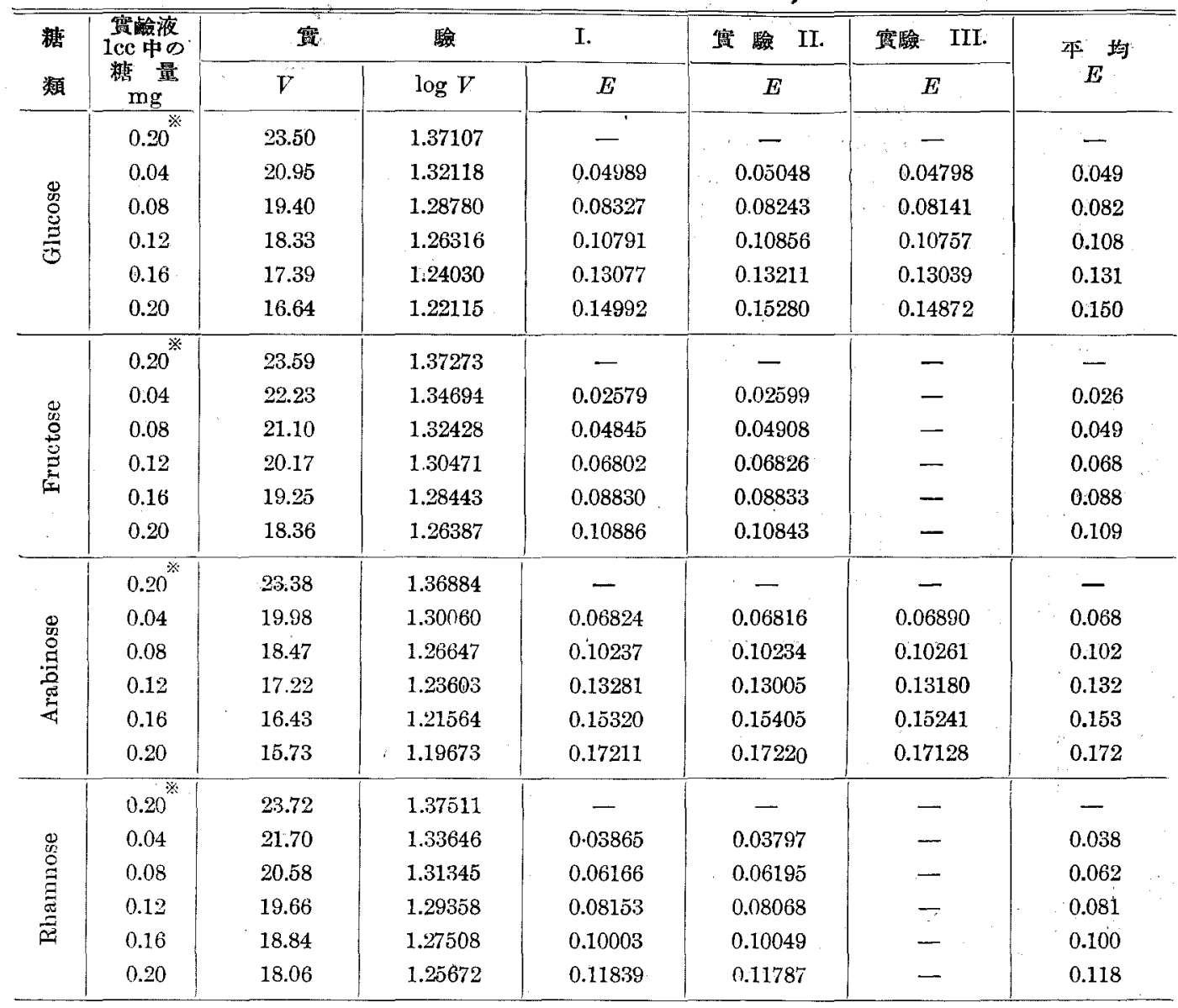

※ Orcin を加一ざる踌照液

時の對照液は $1 \mathrm{cc}$ 中に當該の煻を $0.20 \mathrm{mg}$ 含む溶液 $1 \mathrm{cc}$ K Orcin を溶解せざる硫酸 (1+4) 2cc 及 び反應硫酸 $15 \mathrm{cc}$ を加へて $80^{\circ}$ に20 分加溫後急冷しをるのである. 光源は Leitz 製 Monla に6 ヴ ォルト電池を連結し又之に對する濾光液は $1 \mathrm{cc}$ 中に銅として $7.5 \mathrm{mg}$ を含む硫酸銅水溶液を $2 \mathrm{~cm} の$ 厚さにして用みたのである．との時の賽驗絬果は穿五表並に第 5 圖の通りである.

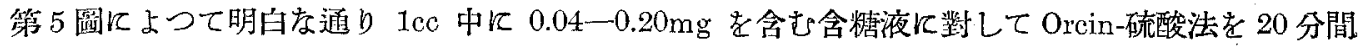
試みればその呈色度は含糖量に正比例する，夫敌に前項に於て記载したる方法によつて時間曲線と 對此的線とを求めて先づ定性を行ひ然る後正性された楉類（一種の時又は数種混合の時もる）につ いて前記の通りに加溫時間 20 分の濃度曲線を作成して然る上此の濃度曲線に供試液の $E$ を對照すれ

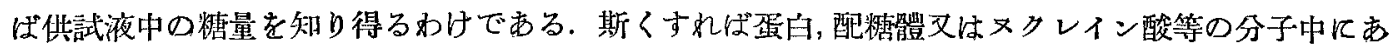




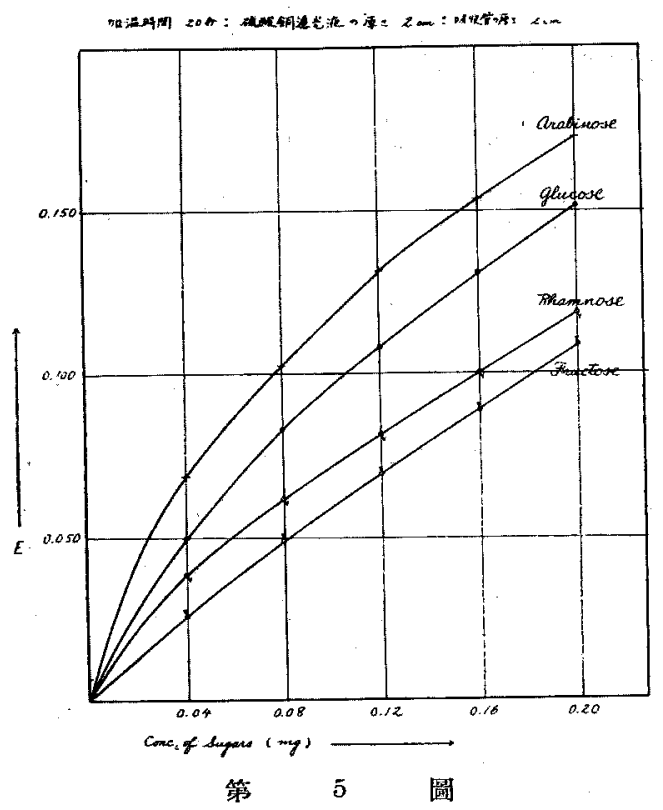

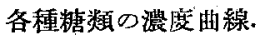

る微量糖類が容易に而正正確に定性し且つ定量し

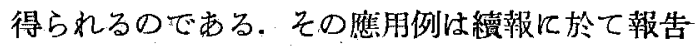
する豫定である。

\section{要 約}

1. 糖類の溶液に Tillmans 及 Sorensen 0 Orcin硫酸法を試みれぱ加溫反應時間に應じて色調之色 度とは變化するが此の變化は各種の糖類によつて 特異的でする。

2. 此の特異的な變化はセシウム光電管を裝借: せる炕電光度計によつてる測定し得られるこるを 證明した。

3. Glucose, Mannose, Galactose, Fructose, Arabinose, Xylose, Rhamnose 等次て Orcin-硫酸 法老試み光特の色調と色度との反應時閒的變化を 時間曲線と對比曲線にて示し, 然る上, 兩曲線の形 狀亚儿對比曲線の位置々何れる煻の種類によつて 特異的であるが故に此の雨曲線によつて糖の種類

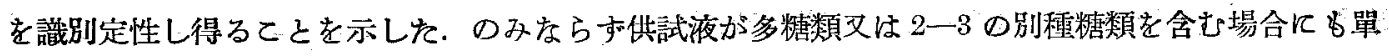
糖類の特異的時間曲線乙對比曲線とが夫々加成的飞表はれるが故に本法によつて自然物中の微量糖、 類の定性を正磪になし得ることを示した。

4. Orcin-硫酸法による呈色度は反應時間を一定 ( 20 分) にすれば供試糖量 ( $1 \mathrm{cc}$ 中 $0.04-0.20 \mathrm{mg}$ ) に比例するてとを確め得炎. 夫故に此の呈色度を光電光度計にて測定して各種の䌅類又はその混合 物の濃度曲線を作成すれば各種の微量糖類を定量することも可能ですることを示した。 